\title{
PRIVATIZATION OF PUBLIC ENTERPRISES IN NIGERIA: VALUATION ISSUES AND PROBLEMS
}

\author{
Aluko Bioye Tajudeen \\ Department of Estate Management, Obafemi Awolowo University, Ile - Ife, Nigeria \\ E-mail: btaluko@yahoo.com
}

Received 3 November 2004; accepted 24 November 2004

\begin{abstract}
Privatization of public enterprises is a rapidly growing phenomenon in developing countries. However, it requires a lot of policy decisions and careful planning, which depend on high-quality accounting and valuation data. But, the major controversy which trailed the first phase of privatization programmes in Nigeria is the asset valuation methodology. This article therefore examines valuation issues and problems besetting divestiture of public enterprises in the country and offers suggestions toward improving upon the quality of asset valuation for privatization.
\end{abstract}

Keywords: Privatization, Enterprises, Asset Valuation, Issues, Problems.

\section{Introduction}

For many years, up to the early 1980 s, Nigeria, in consonance with Keynesian theory, made fairly extensive use of public enterprises (PEs) for resource mobilization and allocation, particularly, within the social services and utilities sector [1]. By the 1980s, the number of PEs at the federal level alone had reached about 600 and, 900 smaller ones at the state and local government levels. Of this investment estimate, public utilities (PUs) - PEs producing hardcore infrastructure such as electricity, water, telecommunications and transport - accounted for about $37.4 \%$ [2].

Nevertheless, in spite of the huge investments in PEs in Nigeria, they perform poorly both in terms of output and financial returns on Capital. In real terms, the Federal Government returns on these investments were not more than $2 \%$, when the rate of return in the private sector averaged 15\% [3]. While, for instance, the annual grant to National Electric Power Authority (NEPA) was on the increase, it was estimated in 1993 that the inefficiencies in the power sector alone created economic losses of over US \$ 800 million annually [4]. Therefore, with the magnitude of economic problems which confronted Nigeria, especially since the early 1980s - stagnant growth, rising inflation, unemployment, food shortages and mounting external debt - the importance of economic reform, through privatization, began in 1988 with the overall objective of achieving economic efficiency. The Technical Committee on Privatisation and Commercialisation (TCPC) now Bureau for Public Enterprises (BPE) was charged with the task of handling privatization process. By the end of 1993, when this first phase was concluded, 86 firms were privatized [5].

Recently, the Federal Government has commenced the second phase, and, these programmes require a lot of policy decisions and a great deal of careful advance planning from both a political and economic standpoint. And, most privatization decisions depend on high-quality accounting and valuation data [6].

Asset valuation do have a role to play in the provision of more strategic business advice in privatization but the valuer will need to understand the client's (PEs) wider business needs including privatization concept 
and how property plays a part in the client's business. And, a major controversy that has trailed the implementation of the first phase of the nation's privatization programmes is the methodology for determining the value of assets of the companies to be privatized [7]. Certain valuation issues and problems as well as the necessity for valuation itself, are often not well understood in privatization exercises.

Against the foregoing, this paper, therefore, examines valuation issues and problems as they affect public enterprises privatization in Nigeria. Such issues, as examined in turn below, include problem of defining enterprise asset, the need for the valuation as well as asset valuation process. Unique problems inherent in the valuation of Nigeria's Public Enterprises were further discussed with a view to improving the quality of valuers' strategic and operational property advice for the public enterprises undergoing divestiture.

\section{The need for asset valuation in privatisation programmes}

The other most crucial issue in the divestiture process, apart from reasonableness of value arrived at, is the need for valuers to undertake valuation and pricing of enterprises earmarked for sale [8]. In the country, some believed that the financial position of an enterprise is demonstrated in published accounts, particularly balance sheet and profit and loss accounts. It is argued that the balance sheet enables an analyst to use ratios (e. g., current assets to current liabilities) and turnover rates (e. g. of stock). In particular, many investors and managers treat ratios of earnings to capital employed as useful guides in investment decisions and in privatization programme.

Usually, the balance sheet is the enterprise's invitation to the financial market to participate in profit. The proponent of this also found support in Westwick (1980) who classified most important users or readers of balance sheets and published accounts who are incidentally, in most cases, interested in privatization, as follows [9]:

(a) The equity investor group including existing and potential shareholders.

(b) The loan creditor group including existing and potential holders of debentures and loan stock, and providers of short term secured and unsecured loans and finance.

(c) The employee group including existing, potential and past employees.

(d) The analyst - adviser group including financial analysts and journalists, economists, statisticians, researchers, trade unions, stockbrokers and other providers of advisory services such as credit rating agencies.

(e) The business contact group including customers, trade creditors and suppliers and, in a different sense competitors, business rivals, and those interested in mergers, amalgamation and take overs.

(f) The government including tax authorities, departments and agencies concerned with the supervision of commerce and industry, and local authorities.

(g) The public including taxpayers, ratepayers, consumers, and other community and specialist interest groups such as political parties, consumer and environmental protection agencies or societies and regional pressure groups.

But, since price change is apt to prompt demands for up-to-date values in the balance sheet and because ordinary accounting is in the main a historical record, balance sheet is an imperfect means for giving current information. Consequently, there is the need for asset valuation to be prepared by estate surveyors and valuers if balance sheets are to have any meaning to their readers and users in privatization programmes.

The two main areas of weakness are income measurement (especially in terms of general price change), and asset valuation (whether general prices are changing or not). For example, the net asset position shown on the balance sheet is often based on five broad accepted accounting principles or practices as follows [10]:

(a) The stated value of asset not held for resale should be based on their cost regardless of their market price.

(b) The stated value of assets held for resale should be based on their cost or market price whichever is lower.

(c) A mere rise in market price is not a profit, but if the asset is held for resale, a mere decline in market price is a loss.

(d) Nothing can bring profits except what has been sold.

(e) In general, under-statement is „,conservative“ and commendable; over-statement is dishonest and reprehensive.

These principles often give rise to figures, which are fantastically out of line with the facts, but accountants are always ready with a pat justification for each. Several reasons are usually adduced for holding onto 
these principles. For instance, we may say, that accountants are primarily interested in how profitable the enterprise is now and as it has been in the past. The economist including a valuer, an applied economist, is interested in the „might have been“, as well as the actual situation.

Furthermore, in accounting, price is largely treated as a datum and a constant. In economics, price is usually treated as a variable. The economist asks himself what would have happened if there had been a different set of prices, exchanges, transformations, or withdrawals from that which actually occurred. Would the enterprise be better off now, or, worse off? In particular, the economist is interested in the best pattern of behaviour that is, the pattern of behaviour, which places the enterprise in a position superior to that, which can be reached by any other pattern of behaviour. Achieving this best pattern is what the economist meant by „maximizing behaviour“.

In spite of the practical difficulties in the way of maximizing profit, the economist's theory of maximization, which is known usually as the marginal analysis, has a good deal of merit in business valuation. Decisions are always made in the hope of the future, whereas information is always derived from the past. They represent a "might be“ or „potentialities“ as being adopted by economist as well as estate surveyor and valuer in the definition of open market value rather than an „is" and they are, therefore, not, perhaps, congenial to the accountant's insistence on the measurement of the actual. It is potentialities, however, rather than actualities, which are most significant in the making of decisions, and in so far as we regard the whole process of information collection and processing in the organization as essentially an aid to the making of decisions, these potentialities are even more important than the actualities.

Another plausible reason, although the accountant might deny this, is that the accountant has a focus of interest in certain aggregates and totals, such as net worth or aggregate profit figures, whereas the economist is more interested in the structure of the enterprises. Besides, the accountants are not interested primarily in the actual assets, but were concerned almost exclusively with book figures and supporting vouchers, so they could easily be deceived - and so is the investing public.

Although, it would be wrong to regard valuations as being the sole criterion of a company's performance, but, frequently, too much emphasis is placed on asset valuations and too little upon the cash flow and liquidity of the business. Consequently, it is quite possible that asset valuations may mask inherent weaknesses in a company's underlying business. Nevertheless, the prudent management of property cannot and does not proceed without the owners and managers being aware of the underlying value of their property portfolio and its elements. It is only by this means can they determine whether or not they have a balanced portfolio, whether property needs to be bought or sold, whether it is in need of redevelopment or other positive action. Similarly, unless management is aware of the underlying value of the property, the true income potential will not necessarily be obtained on reversions.

Germane to the forgoing, is the view almost gaining acceptability with the Bureau for Public Enterprises (BPE), until contested by the Nigerian Institution of Estate Surveyors and Valuers, that quantity surveyors are better equipped to give asset value, particularly, specialised building types. While the role of quantity surveyors may be complimentary in supplying current costs of building items, value and cost are not the same; more so, that consideration of several other factors such as general level of the economy, the demand and supply factors for the products of the enterprise, nature and state of the enterprise and location are equally relevant for a good valuation. Besides, by the provisions of the Act No. 24 of 1975 establishing Estate Surveyors and Valuers Registration Board of Nigeria (ESVARBON), only registered estate surveyors and valuers in the country can undertake any real estate valuation.

\section{Asset defined}

Experience tells us, for instance, that an enterprise normally must have physical resources to generate its future receipts; therefore, information about these resources is of interest in privatization. We have learned, too, that the enterprise needs a liquid asset, at least, a borrowed fund, if it is to stay solvent. Thus, what an enterprise owns is an asset while what it owes to the outside is a liability. The concern of this paper is the asset valuation of an enterprise.

In normal accounting practice, assets are classified as fixed or current assets. Fixed assets are those, which are intended for use in the activities of a company on a continuing basis. The main concern of the valuer will be tangible fixed assets, which include land and buildings and plant and machinery, as well as fixtures and fittings and tools and equipment. The asset valuer will not generally be concerned with current assets which include stocks, debtors, investments and cash not intended for use on a continuing basis. 
Fixed assets can be categorized into either specialized or non-specialised property or as plant and machinery. Specialized properties are those which are unlikely to be sold in the open market due to their particular construction, location or size - for example, oil refineries, chemical works, power stations and dock installations. Non-specialised properties are those for which there is a general demand and where there is likely to be market evidence so that open market value will normally be the basis of valuation. Also, plant and machinery assets will form either part of a building's service installation, in which case they are normally included in the valuation of the land and buildings, or process plant and machinery which is specific to the occupier's operations and are valued separately.

It is also important for valuers to note that assets can be classified according to the purpose for which they are held. The Red Book (RICS, 1990; 1999) identifies the following categories of fixed assets [11]:

(a) Land and buildings owner-occupied for the purposes of the business and, may be either non-specialised or specialised;

(b) Land and buildings held as investments. Investment properties are those held for income and/ or capital appreciation;

(c) Land and buildings held as trading stock and work in progress;

(d) Land and buildings fully equipped as an operational entity and valued having regard to trading potential (hotels for example);

(e) Land and buildings held for development;

(f) Land and buildings in course of development;

(g) Land and buildings classified as a wasting asset; and

(h) Land and buildings surplus to the requirements of the business.

In the absence of specific instructions from directors, the valuer will be obliged to make a factual determination of the most appropriate classification of each asset based on knowledge, experience and expertise. In addition to the above, what constitutes asset depend on the accounting policy as well as the business type of the enterprise to be privatized. For instance, the asset of a flourmill will be quite different from that of Cocoa- processing industry. The accounting policy of the enterprise to be privatized will also specify how the assets are to be classified or state the criteria to be adopted in distinguishing a fixed from a current asset for the purpose of inclusion in financial accounts or statement. In most privatisation valuations, such as in Lagos State Water Corporation (LSWC), asset register prepared by a firm of Chartered Accountants was helpful. Nevertheless, valuers were weary of relying hook, line and sinker as most of the items reflected as assets by accountants are not acceptable to them. A fence wall and the main building, for example, which are valued as one entity constituted separate items in the register for accounting purpose.

Furthermore, according to World Bank, water industry assets can be classified into three, namely: water supply (production facilities, transmission and distribution system and administrative infrastructure [12]. On the other hand, the valuation consultants engaged adopted a slightly different classification in the valuation of LSWC assets as they classified the assets into three such as land, civil works and buildings, water work assets and other assets such as furniture and fittings, equipment, motor vehicles, electronics etc. While the World Bank's classification was meant for the purpose of re-engineering and rehabilitating the LSWC, the other was undertaken to assist the corporation to mobilize funds and convince prospective private sector partner in its privatization drive [12]. Perhaps, we may say that defining, listing and classification of asset depends on the nature of the industry under consideration, the purpose of valuation and, more importantly, the users of the valuation.

\section{The valuation process}

Valuers are engaged to update values of the fixed assets in the balance sheet in order to attract investors since they prefer an invitation in the form of a forward-looking valuation rather than historical record of the enterprise as a whole. To accomplish this task, ideally, a valuer needs to know the client's plans and intentions for the asset, nature of the industry to be valued, the privatisation technique to be adopted and the intended use of the valuation report. For example, in previous privatisation valuations in Nigeria such as in banking and finance, mining, and water sectors, most asset involved include plants and machineries, lands and buildings; and furniture, fittings and equipment. The government's determination to extend the exercise to the utilities (power and telecommunications) - Nigerian Electric Power Authority (NEPA) and Nigerian Telecommunications Limited (NITEL), Nigerian Airways, Nigerian National Petroleum Corporation (NNPC) with all its petroleum refineries and petrochemical plants will afford valuers opportunity to improve on their experience. The new assets, although not necessarily the same with the previous ones consist of production facilities, transmission and distribution system and, administrative infrastructure such as offices, workshops, 
depots and stores facilities and housing for operating personnel; and others like vehicles and mobile plant and workshop, communications and training equipment and tools, data processing equipment, etc.

Moreover, central to the valuation are the techniques to be employed in privatising the enterprise. The disinvestment process already employed in the country to transfer state enterprises to the private sector include one or more of the following:

(a) by a stock exchange flotation to allow for public share offering: A total of 35 public enterprises were privatized, during the first phase of the exercise, through this method, and over 1.5 billion shares were sold to Nigerian citizens and associations in all the local government areas across the country;

(b) by negotiation and private treaty, otherwise known as deferred public offer. Four hotels were privatized this way, through negotiation between willing buyers and willing sellers (core/ investors), but, on the condition that the new owners would sell not less than 40 per cent of the equity to the Nigerian public within 5 years of the take-over;

(c) by trade sales: where a state-owned enterprise, particularly, small or medium sized enterprise, is moribound and no interests shown by investors, liquidation is preferred. A total of twenty-six enterprises were privatized this way, out of which 18 were done by the Federal Ministries of Agriculture and Transport before the establishment of TCPC in 1988;

(d) by a management-employee buyouts: Only one enterprise was privatized in this manner;

(e) by competitive tendering: for such local government services as garbage collection, street cleaning, catering for the elderly and government office cleaning;

(f) by deregulation: and,

(g) by joint ventures: a hybrid approach which reflects elements of other methods including negotiation and private treaty and competitive tendering.

The valuation discussed below relate to the first three although, some of the contents of the paper might be useful with respect to options (d) and (g).

\section{1. Bases and Methods of Valuation}

In attempting to value assets of utilities in power and telecommunications, airways, petroleum refineries and petrochemical plants in the next phase of the privatization programme, two known bases of value for business purposes, vis-a-vis, open market value on existing use and alternative use bases, explained below, are proposed.

\subsection{Market Valuations on Existing Use Basis}

A valuation on existing use basis is defined as the value of the property in the hands of a purchaser as part of the assets of an established business for which they were designed to be used [13]. This is similar to Bonbright's concept of „value to the owner" and Horsley's ,value to the enterprise“ $[14,15]$. Besides, concepts like „value-in-use“ and „going concern“ were likened to „existing-use" basis [16, 17].

We must appreciate that an enterprise derives its existing use value through its own ability to generate earnings, not by holding an asset package others could use to produce a different level of earnings. Thus, because the value estimate represents the value of the business itself, individual value amounts may not normally be apportioned to any particular asset. Therefore, individual assets have no going concern value and this basis has no place in asset valuations for financial reporting/balance sheet necessary for flotation of shares on the stock exchange. Nevertheless, existing use value reflect the extent to which the property contributes to the utility or profitability of the enterprise of which it is a part. It refers to an appraisal of the worth of a business property asset (rather than an investment property asset) on behalf of an occupier (rather than an investor) [18].

Assets of an enterprise, especially owner-occupied properties, which may include production facilities, distribution system and administrative infrastructure etc, to be privatized through stock exchange flotation or by negotiation are normally valued on existing use basis. Valuations of owner-occupied properties assume a continuing or ongoing business (existing use), ignoring any possible alternative use, any element of „hope value“, any value arising from goodwill and any special increase in value arising out of a special transaction which would leave the company with an interest different from the one which is to be valued (e. g., sale and leaseback). The value of those assets is, therefore, to the owner-occupier and is a similar amount that it would cost to replace the assets in its existing state. This is called "deprival value" in accountancy concept and, which can, in valuer's terms, be defined as ,net replacement cost“.

In arriving at the open market value on existing use basis, a Depreciated Replacement Cost (DRC) approach is adopted. Depreciated Replacement Cost 
approach is the current cost of acquiring the site in its existing use and erecting the premises, less an appropriate deduction for their present condition. But, some enterprises like hotels, banks, telecommunications, electricity, etc, have incomeproducing properties purchased with the intent of realizing future profits. The production cost, unlike profit/ accounts method of valuation, often bears little relation to the value of the enterprise. The DRC method is concerned with the valuation of individual assets rather than the business per se. It is essentially different from the going concern value methods and concepts and is properly used in asset valuations for financial statements. Notwithstanding this deficiency in cost approach to value, falsification of accounts or non-disclosure of correct state of accounts or production of different accounts to meet different objectives by the same enterprise, either to evade or avoid taxation, which is very rampant in the country, makes the use of accounts/ profit approach to valuation almost impossible.

Therefore, any valuation prepared on a DRC basis must be made subject to test of adequate potential profitability, or service potential in the case of public assets or assets devoid of free cash flows, related to the value of the enterprise as a whole. Thus, it combines elements of market and non-market considerations. However, it is a matter for the directors to decide whether or not the business is sufficiently profitable to enable the property to be carried on the balance sheet at the value arrived at by this method or whether it should be included at a lower value.

Generally speaking, owner-occupied properties, that is, those in use by the undertaking itself, may be either non-specialised or specialised as explained above. For those non-specialised properties like residential accommodation, shops, offices, factories and warehouses that are for the occupation of the business, the asset valuation for privatization will be on the basis of open market value for its existing use. Any value attributable to special adaptation works must be taken into consideration.

Furthermore, there are certain classes of specialized property, which are rarely, if ever, sold, and where no evidence of market value exists, and it is for these types of property that the DRC basis of valuation is used. Examples of such property are the following:

(i) Properties, which consist primarily of specialised plant items where many of the buildings will consist only of cladding to plant structures supporting specialized plant items, e. g., oil refineries and specialized chemical plants. (ii) Properties where the buildings and site works are designed specially for the owner's business and are unsuitable for any other use, e. g. docks.

(iii) Properties of such a size or special design or situated in a particular geographical location such that it is not possible to arrive at a valuation based on evidence of open market transactions.

Fixtures and fittings are very difficult to value as they are items of chattel that can be moved about easily. Care has to be exercised by the valuer to take accurate inventory and analyses of the stock and to provide for discount to reflect the age and condition of each of the item against the replacement cost. It is equally important that the assets of an enterprise to be privatized which are in the course of development, if they are for occupation by the business, should be valued having regard to their existing state and current costs at the date of valuation on the DRC basis subject to adequate potential profitability on completion. Also, property occupied by a company under an intercompany leasing arrangement within a group, whether formal or informal, is valued as owner-occupied as described above.

\section{3. Market Valuations on Alternative Use Basis}

This basis assumes that the business enterprise will be discontinued and has been likened to „hope value“, „gone-concern value“ and „break-up value“ [19-21]. The valuation concept gives what could be realizable value if the net tangible assets of an enterprise are sold in the open market between a willing seller and a willing buyer. Thus, in the event of the firm ceasing to trade and there being no possibility of selling it as a going concern, then the open market capital value of the proprietary land unit/ asset is of great importance to the managers, investors, creditors, owners or shareholders of the firm so that a „break-up“ value has to be determined.

This basis is normally adopted in asset valuation of an enterprise where trade sales or negotiation (with core investors) and private treaty technique of privatization is adopted; as this involve either downsizing an enterprise to dispose of some assets or wounding up of a company which could not be sold as a going concern. The alternative use valuation is, nevertheless, an open market valuation and is defined as [22]:

„the best price at which the sale of an interest in property might reasonably be expected to have been completed unconditionally for cash consideration on the date of valuation, assuming:

(a) a willing seller; 
(b) that, prior to the date of valuation there had been a reasonable period (having regard to the nature of the property and the state of the market) for the proper marketing of the interest, for the agreement of price and terms and for the completion of sale;

(c) that the state of the market, level of values and other circumstances were, on any earlier assumed date of exchange of contracts, the same as on the date of valuation; and

(d) that the account is taken of any additional bid by a purchaser with a special interest".

Valuation of assets of an enterprise for public share offering at the Stock exchange in privatization exercise like balance sheet valuation should not reflect alternative use value since normal accounting concepts assume an ongoing business; and, where properties are occupied for the purpose of the business, alternative use values, which could only be realized on liquidation, closure or removal of the business to other premises, are not suitable for inclusion in the accounts.

There may, however, be instances where an owneroccupied property will have a higher value for a prospective development or conversion for some other purpose than the existing use; it is for the directors to decide whether they should move to alternative premises and realize the potential value of the existing premises. The valuer can, in this instance, report the alternative use values of those assets, whether or not public share offering or open treaty privatization technique is adopted, to assist the directors in decision-making. Obviously, this decision will be affected by such factors as costs of removal, redundancy payments, disruption of business with consequential loss of profits, adaptation costs, availability and cost of purchase or leasing new premises, and so on.

In view of the foregoing, it is agreed that where company assets or properties, such as, properties held vacant pending disposal, held as stock, or held as investments, have been declared by directors as being surplus to trading requirements, whether for public share offering or outright disposal in the market, their open market valuations for alternative use without the qualification for the existing use is required to be carried by the estate surveyor and valuer. This will reflect the potential for alternative uses, if any, that can be realized by the company for these properties without any effect on the trading position. Besides, for properties held by the undertaking as investments, an open market valuation on alternative use will also be appropriate.
Any of the method or methods of valuation that is/ are most appropriate to arrive at the open market value of the assets an enterprise (to be privatized) having possibility of alternative use apart from the current operation could be used. These include comparison, residual, investment and profit methods. The open market valuations, which seek to establish the investment value of assets if sold out of the business of the enterprises, are required:

(i) by sellers wanting to know how much they might expect to achieve;

(ii) by buyers wishing to know how much to offer;

(iii)by bankers and lenders for loan security purpose;

(iv) by accountants handling the affairs of failed companies; and,

(v) by accountants investing in companies with financial problems.

Market valuations of assets on alternative use basis are carried out through recent evidence from sales and transactions except where specialized public buildings or plants which rarely exchange hands in the market are being handled; in this case, DRC subject to the test of adequate potential profitability is employed. Through this process, the disposal value or scrap value of a manufacturing concern valued as ,stopped works“ could be determined.

The alternative use values of assets of an enterprise to be privatized, which are shown either in the balance sheet or as a note in the auditor's report, are useful guides to managers, investors-actual or potential, analysts, etc, in investment decision-making as follows:

(i) Open market value for alternative use is the minimum value of the business. A seller would therefore be irrational to sell at a lower figure; and it would always be worthwhile to buy a business or company asset at a figure below its alternative use value (allowing, of course, a tolerance for the uncertainty of an alternative use value estimate)

(ii) The alternative use value of assets gives some indication of their possible salvage value when they are to be disposed of. Though, bad management or misfortune may result in this salvage value being dissipated as time goes on; but, at least, this value is available when the investment is first made.

(iii) The alternative use value gives the minimum liquidity available to the owner; subject again to the size of any losses incurred after the investment is made.

(iv) Finally, by having access to the alternative use 
values of the company assets in the open market reflected in the balance sheet, the directors or would-be private investors taking over the affairs of the company could take policy decisions for the overall success of the business. For instance, they could determine the assets that are surplus to company requirements or redundant and how they could be gainfully employed elsewhere. Also, if, of course, a property with a high alternative use value is the company's only or major asset, it might be better to liquidate the company and realize the value of the asset.

\section{Valuation Problems in Privatisation}

Some of the problems which characterized most industrial or company valuations, particularly during the first phase of the privatization experience in the country, are examined below:

(a) Asset referencing and inventory - Asset registers are not available for most enterprises. Even, where available the information is often not comprehensive enough to assist the valuer. More time is required to extract useful information from loose ledgers, invoices, bank statements and other sources. Where accountant prepares the asset register, the concept of asset is usually in conflict with valuers' concept. For instance, while renovation to a fence wall or repair of roof, for example, may be regarded as separate assets in the accounts, but, for valuation purposes, these items are component parts of the entire building whose impact are reflected in the overall value of the premises.

(b) Attitude of workers toward privatization - The workers of enterprises being privatized hardly co-operate with valuers thereby making valuation inspections difficult. They see privatization as a way of divesting them of means of making their livelihood. The labour unions of both Nigerian Telecommunications Limited and Nigerian Airways Authority have resisted several attempts to value their assets and pivatise them. But, with adequate publicity (public relations) and labour relations that explain how they are to be accommodated in the exercise, their fears could be allayed and, co-operation guaranteed.

(c) Land titling and ownership matter - Most of the public enterprises do not own land on which they are sited; they only enjoy use rights but not equity rights. The lands were acquired by executive instruments and by undocumented declarations by either political or traditional authorities. For example, the Nigerian Airways Authority owns half of Ikeja, a state capital in the country and, over 300,000 ha of land nationwide with no single title document. Also, of the 720 parcels of land belonging to the Nigerian Telecommunications Limited (NITEL), only 30 have title documents. The Nigerian Railways with large expanse of land throughout the country has title document for only 50 ha. By virtue of the divestiture programme these lands have become subject of protracted litigation. There are, therefore, claims for compensation from former, original landowners and requests that the lands revert to them because land use, that is, for social use, has changed. Any valuation of land use rights needs to take into consideration the legal rights of transferability to their parties and claims of former owners.

(d) Income Measurement - Valuers often rely on financial statements or accounts prepared by accountants for the asset valuation. But, while the estate surveyors and valuers adopt current values of assets, the accountants are more concerned with the historical cost. There are two kinds of defects arising from this. In the income statement, the use of historical cost during inflation leads to the fabrication of profits where none exist - much as if every statement contains an arithmetical blunder that boosts profit. In the balance sheet, historical figures ignore gain that exists in reality. Besides, misusing references to alternative use of value, current assets, fixed assets, intangible asset, etc contriving the term asset or existing use value, and abusing other phrases tend to undermine our credibility. With improved education and retraining of estate surveyors and valuers, and the establishment of a joint committee of accountants and valuers toward promoting universally acceptable semantics and concepts for the two professions, the quality of asset valuation would be enhanced. Improved communication and understanding between the valuer and client and/ or clients, accountant, banker, investor, manager, analyst and lawyer is an important goal in privatization.

(e) Lack of comparable market data - Property market information are highly specialized and localized leading to inaccurate valuations; and, this further makes adoption of market comparison approach for administrative facilities on alternative use basis difficult. Information supplied by valuation clients are often not reliable or inadequate. Also, there may be insufficient number of transactions to guide a 
valuer as to the "going rate" in the market or cost $/ \mathrm{m}^{2}$; or, there may be sufficient number of transactions but the information is not made available. Alternatively, the attributes of assets involved in market transactions which form the „comparable“ evidence are sufficiently different from the property to be valued or priced as to create serious difficulties in translating the evidence with any degree of confidence. The development of historical data services or centralized database by estate surveying and valuation companies to allow forecasting at national, regional and local market/city levels by sector is suggested in the country; the type that is comparable to the Drivers Jonas/ Investment Property Databank Limited (IPD) and WM Company Limited (WM) in the United Kingdom.

(f) Outdated Valuation Standards and Guidance Notes - The valuation standards prepared by the Nigerian Institution of Estate Surveyors and Valuers in 1985 for guidance in asset valuation have become obsolete and need updating for the ongoing privatization programme [23]. They do not conform to generally accepted international valuation principles because of political considerations and, perhaps, the failure to appreciate the significance of utilizing international standards to met the needs of investors from market economies who understand and expect to have financial data prepared in accordance with such standards. In Nigeria, as a way out of this problem, UK valuation standards as set out in the Appraisal and Valuation Manual, colloquially known as the „Red Book“ are employed by valuers [24]. Nevertheless, it has been argued in the Mallinson Report that the Red Book is prescriptive and UK-specific; and, consequently, may not conform with the conditions in the Nigerian property market [25].

(g) Valuation accuracy - Privatisation decisions depend on high quality valuation output. Public criticisms have trailed the valuation figures obtained for assets of the Nigerian Postal Services Limited (NIPOST), NICON NUGA Hotels Abuja and, a host of other utilities being privatized in the country. Governments, also, often give priority to rapid privatization which makes accurate valuation almost impossible. Therefore, every attempt has to be made to avoid the public perception that assets were undervalued and sold too cheaply or that they were overvalued and could not be sold because prices were too high to attract investor (s).

(h) Employment of Valuation Consultants - Absence of high quality professional advice can mar the privatization programme. The BPE has continued to insist on partnership between local and foreign valuers before they are engaged. They maintained that the technical and financial proposals, work plan and methodology as well as the quality and presentation of expression of interests submitted by local valuers are usually substandard [26]. Although, this may contravene the law establishing the valuation profession in the country, it will provide opportunity for valueadded through the training and transfer of knowledge to BPE staff and/ or Nigerian Valuers.

(i) Miscellaneous problems - Several other problems affecting valuation of utilities, particularly, industrial or manufacturing concerns, during the divestiture programme include:

* Problems do arise in deciding if an item should be included in the valuation as part of plant and machinery or simply taken as part of buildings. Some common items usually affected by this are air-conditioning installations, heating boilers, water and gas services, fire extinguishers to mention a few. Obviously, if the prime purpose of a cooling system (an airconditioning installation) is to assist in the manufacturing process, such should then be valued with the plant and where not, it should not;

* As a result of the pace of technological advances, most plant and machinery assets and computer systems in privatising industrial establishments are outmoded and pose serious challenges in their valuations. Most often, valuers have to rely on interpolation of original cost price allowing for foreign exchange differentials, depreciation and inflation rates foreign and local. This is more of guesswork and imputation which does not augur well for the future of the profession;

* Determination of the service life of a plant or machine when applying the depreciation method;

* Lack of willingness of local suppliers to give the price list on plant and machinery equipment. Nigeria is a special market to suppliers of machines - so the correct cost is usually not given. A plant that would, ordinarily, cost $\$ 5,000$ to assemble in other African countries may be inflated to a figure as high as $\$ 30,000$ in the country. Even, where overseas' manufacturers and suppliers are contacted for cross-referencing, valuers are usually redirected back to their local 
representatives;

* There are other charges (public relations) which are incidental to clearing of machines from customs in Nigeria; a direct consequence of the level of bribery and corruption in the country without which delays or frustrations may be experienced. Thus, payment of such would ensure free movement of machines or equipment from the port to their destinations;

* Nigeria importers of machines load their invoices to take foreign exchange out of the country; so the invoices are not reliable evidence for proper valuation work; and,

* Fluctuation of the value (devaluation) of Nigerian currency on weekly and daily basis in the international money market affects the value of industrial enterprise.

It is suggested that with continuing professional training, research, education and relevant experience in this specialist area, the forgoing problems could be overcome by the valuers.

\section{Conclusion}

We have examined in this paper the relevance of asset valuation to privatisation. It can be seen that the current values of assets assessed by estate surveyors and valuers, and incorporated into the company accounts including balance sheet would serve as public enterprise's or firm's invitation to the financial market to participate in the profit. A proper valuation will serve, at least, as a benchmark or as a guide to the sales price, even, when there is only one buyer.

Notwithstanding the foregoing, asset valuation for privatisation is beset with a number of issues and problems already examined in this paper. Perhaps, to be able to address these bewildering issues and problems, it might be necessary for both the Nigerian Institution of Estate Surveyors and Valuers and, its regulatory body, the Estate Surveyors and Valuers Registration Board of Nigeria in conjunction with other relevant professional bodies update 1985 standards and come up with standards on asset valuation for privatisation. The standards, hopefully, will provide: codification of good practice, help and guidance to valuers, a standardization of approach to the users of valuations, a voluntary and self-regulatory system of control on valuers based on professional expertise and not based on another profession's views, some form of discipline on members where they can be made accountable for discreditable conduct and to the public at large, the highest standards of professional competence. Finally, property advice either to the business occupiers of public enterprises or prospective investors needs to be linked to the core functions of the business and valuers need to appreciate the implications that property has for business processes and privatisation.

\section{References}

[1] Ayodele, A. S. Issues in The Privatization of Public Enterprises in Nigeria. Bullion - publication of The Central Bank of Nigeria, Vol 23, No 3, July/ September 1999, p. 12.

[2] TCPC (1993), Final Report Vol. 1 (Main Report), Bureau for Public Enterprises, Federal Secretariat, Abuja, Nigeria; Sanusi, J. O. (2000), „Challenges Prospects of Privatisation in developing economy“, Business Times, Monday, May 15, p. 39. 2

[3] Okereke-Onyiuke, N. Social and economic benefits of privatization", being a paper presented at a Privatisation Summit organised by The Nigerian Institution of Estate Surveyors and Valuers and held at Abuja, July 4-5, 2000, 17 p., p.1; Onosode Commission (1984), Report of Federal Government of Nigeria Inquiry on Public Enterprises in Nigeria, Government Printers, Lagos.

[4] ESMAP. Nigeria: Issues and Options in the Energy Sector, No. 11672, 1993, UNI.

[5] Anyanwu, C. M. (1999), „An Analysis of the Nigerian Privatization Programme, 1988 - 1993: Lessons of Experience“", Bullion, Vol 23 No 3, July/September 1999, p. $35-40$.

[6] Coopers and Lybrand and Deloitte. „Implementing Privatisation“, OECD/East-West Accounting Issues Conference, Paris, 25 - 27 September 1990.

[7] Agbebiyi, H.A. (2000), op. cit. p. 21.

[8] Olajide, M. D. Cost-Benefit Analysis Approach to Valuation and Pricing for Privatisation Decisions: A proposal for Nigeria, Africa Economic Analysis, Department of Economics, The American University in Cairo (AUC), Egypt, 2000, p. 1.

[9] Westwick, C. A. Property Valuation and Accounts, The Institute of Chartered Accountants in England and Wales, London, 1980, p. 4-8.

[10] Aluko, B. T.; Ajayi, C. A. „The Estate Surveyors' Versus Accountants' Perspectives on Company Assets Valuation in Nigeria“, The Estate Surveyor and Valuer - Journal of the Nigerian Institution of Estate Surveyors and Valuers, Lagos, Vol 16, No. 2, 1992, p. 29; Aluko, B. T. (1999), „Asset Valuations“, op. cit, p. 10.9.

[11] Royal Institution of Chartered Surveyors (RICS) (1990), Statements of Asset Valuation Practice and Guidance Notes, The Assets Valuation Standards Committee, RICS, London, SAVP1: 3-4; RICS (1999), „Definitions“ in RICS Appraisal and Valuation Manual, 
RICS Business Services Limited, London, p. 1-2.

[12] World Bank (1998), Implementation Report Federal Republic of Nigeria, Lagos State Water Supply Project, Report No: 17980, Water and Urban 2 African Region, Unpublished Report, The World Bank, Washington, D. C., May 21, 48 p.

[13] Turner, D. M. Approach to Land Values, Geographical Publications, London, 1977.

[14] Bonbright, P. Income Property Valuation Vols I and II, Longman, New York, 1936.

[15] Horsley, G. J. (1990), op. cit, p. 25.

[16] ISVC (1997), International Valuation Standards Principles, Standards, and Applications and Performance Standards, International Bureau, London, IVS2-4.

[17] Greer, W. R.; Buono, T. J. Going Concern Valuations. The Appraisal Journal, October 1997, p 587 - 594..15.

[18] Wyatt, P. An Investigation of the Nature of the Valuation Service offered to business occupiers, Property Investment and Finance, Vol 19, No 2, 2001, p. $109 . .16$.

[19] Cullingwood, J. Asset Valuation: Alternative Use Value, Chartered Surveyor, RICS, London, April 1979, p. 360 .
[20] Aluko, B. T. (1989), A Critical Examination of the Valuation Company Assets in Nigeria, B. Sc. (Hons) Degree Dissertation submitted to The Department of Estate Management, Obafemi Awolowo University, IleIfe, $97 \mathrm{p}$.

[21] Baxter, W. T. Accounting Values and Inflation, Sponsored by The Research Committee of The Institute of Chartered Accountants in England and Wales, MacGraw-Hill, Maidenhead, England, 1975.

[22] RICS (1999), op . cit, PS 4, p. 4.20.

[23] The Nigerian Institution of Estate Surveyors and Valuers (NIESV) (1985), Guidance Notes on Property Valuation, 1 st Edition, NIESV, Lagos, 32 p.

[24] RICS. The Appraisal and Valuation Manual, Royal Institution of Chartered Surveyors, London, 1995 a.

[25] RICS (1994) The Mallinson Report: President's Working Party on Commercial Property Valuations, Royal Institution of Chartered Surveyors, London, 1994, p. 27.

[26] Abdullahi, T. M. Preparation of Proposals for Core/ Strategic Investors/ Post Acquisition Plan, National Workshop on Standard Procurement Procedures Organised by BPE and held in Ibadan, 7 p, July 2002; BPE (2002), Selection and Employment of Consultants, Federal Government of Nigeria, Abuja, 15 p. 